\title{
Reducing the Effect of Carbonation and Corrosion in Rice Husk Ash Concrete by Incorporating Polymer
}

\author{
Daddan Khan BANGWAR, Abdullah SAAND, Muhammad Aslam BHUTTO, Muhammad Auchar ZARDARI, Manthar Ali KEERIO
}

\begin{abstract}
Durability plays a vital role in life of a reinforced concrete structural member. To increase service life of a structure, it is important to reduce corrosion potential and carbonation attack. In order to reduce the corrosion and carbonation effect in concrete structures, various supplementary cementing materials are used. In this study, a nove composite is introduced to reduce corrosion potential and carbonation attack on Rice Husk Ash Polymer Modified Concrete (RHAPMC). An experimental work was conducted to check the behaviour of corrosion and carbonation attack in control concrete, cement was replaced with RHAPMC concrete at the ages of 30 and 180 days. The results indicate that the effect of corrosion potential and carbonation has been significantly reduced with the addition of polymer in the cement replaced concrete.
\end{abstract}

Keywords: carbonation; corrosion; polymer; rice husk ash

\section{INTRODUCTION}

Modern concretes tend to crack more easily due to lower creep, higher thermal and drying shrinkages and higher elastic modulus [1]. Some mineral industrial byproducts known as pozzolans when added to normal concretes are highly effective in reducing the heat of hydration, increasing strength and other properties of concretes and mortars [1]. Upon proper curing, concretes and mortars are generally less crack prone and therefore less permeable in service [2]. Cement is generally substituted with different pozzolans in order to improve inbred properties of concrete.

Rice Husk Ash (RHA) is considered to be one of the pozzolanic materials. When RHA is not in ultra-fine state, it disturbs durability of concrete which may lead to failure of structures. In order to improve this deficiency of RHA concrete, a new approach, i.e. incorporation of polymer has been envisaged.

Corrosion and carbonation reduce life span of the Reinforced Cement Concrete structures. Corrosion causes destruction of the reinforcing bars embedded in concrete by reacting with the environment. This reaction is an electrochemical oxidation process that usually produces rust or other metal oxide. Carbonation is the reaction of carbon dioxide in the environment with the calcium hydroxide in the cement paste. The aforementioned chemical reaction produces calcium carbonate which lowers the $\mathrm{pH}$ value at around 9 . For a $\mathrm{pH}$ value of 9 or below, the protective oxide layer surrounding the reinforcing steel breaks down and corrosion becomes possible.

Generally, incorporation of pozzolanic materials into concrete causes modification in the pore-structure that affects permeability of concrete to a great extent. Mehta [3] has shown a noteworthy decrease in the cement paste porosity by incorporating RHA and observed modification in the pore structure of cement paste. Inclusion of RHA in concrete and mortars can improve their impermeability. V. and H-W. Song [4] conducted investigations on the porosity and water absorption properties of RHA concrete. The authors concluded that: (i) Concrete porosity decreased with the inclusion of RHA content due to tiny RHA particles that increased the particle packing density of the blended cement, resulting to a condensed volume of larger pores; and (ii) water absorption coefficient for RHA modified concrete at all percentages dosages of RHA was found to be less as compared to unmodified concrete. Identical to different pozzolanic resources, rice husk ash consumes calcium hydroxide of the cement paste. Owing to this effect, the likelihood of carbonation in RHA concrete and mortar may be higher. Conversely, inclusion of ultra-fine RHA will bring concrete permeability down which may cause lower carbonation.

Latex-modified mortars are excellent in water impermeability which leads the high resistance to chloride ion (CL-) penetration. The chloride ion (CL-) deems to be the most important factor affecting corrosion of the reinforcing bars in RCC structures [5]. Diamanti, M., et al. [6] concluded that polymer-modified cementitious coatings remain highly effective in reducing water penetration, moisture content and chloride ingression in concrete under wet conditions. The high performance concrete may not essentially guarantee an enduring durability in a severe environment unless it is designed for dimensional stability and soundness [7]. The most undesirable characteristics of carbonation are the neutralization of the alkaline nature hydrated cement in concrete [8]. According to Aggarwal, L. K. et al. [9] the improved resistance to infiltration of $\mathrm{CO}_{2}$ makes Polymermodified mortar very helpful in application in corrosion prone domains.

This paper addresses the effectiveness of incorporation of polymer in RHA concrete to counteract carbonation and corrosion attack.

\section{METHODOLOGY}

\subsection{Corrosion}

A total of 30 number cylindrical specimens of size 100 $\times 200 \mathrm{~mm}$ were cast. The mix proportion, workability range and marks of samples are shown in Tab. 1. A bar of $12 \mathrm{~mm}$ dia, $300 \mathrm{~mm}$ in length was placed in the centre of all specimens for corrosion analysis test as shown in Fig. 1. After 24 hours the samples were de-moulded and were kept in the curing tank for curing. The control mix (unmodified) and rice husk ash modified concrete mix samples were cured for 28-days in moist curing as per ASTM C 192 
and polymer-modified concrete mix samples were first kept in wet curing for 7-days and then kept in the air for 21-days for air dry curing as per JIS A 1171-2000. After completion of curing period, all concrete specimens were further put into the water tank containing a solution of $3 \%$ sodium chloride for two weeks. After two weeks of solution curing, samples were taken out of the water tank for air dry curing. Such wet and air dry curing continued for 30 and 180 days respectively. Corrosion potential was determined as per ASTM C-876. The average value of five specimens was recorded as the corrosion potential value of the specimen.

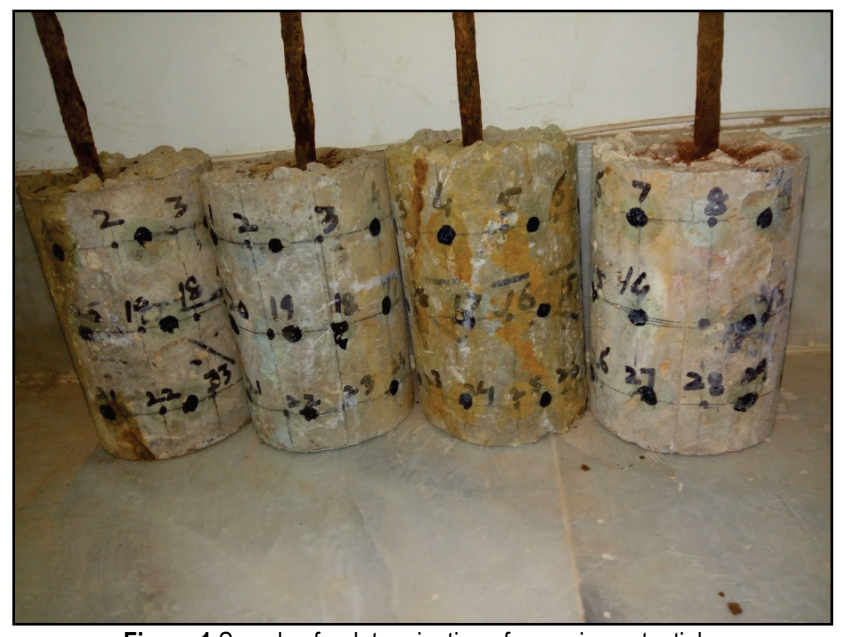

Figure 1 Samples for determination of corrosion potential.

\subsection{Carbonation Attack}

A total of 30 number cylindrical specimens of size 100 $\times 200 \mathrm{~mm}$ were cast and de-molded after 24 hours. After de-moulding all the specimens were kept in the curing tank for curing. The control mix (un-modified) and rice husk ash modified concrete mix samples were cured for 28-days in moist curing as per ASTM C 192 and polymer-modified concrete mix samples were first kept in wet curing for 7 days and kept in the air for 21-days for air dry curing as per JIS A 1171-2000. After 28-days curing, all samples were further kept in lime saturation for the period of 28 and 180 days respectively.

For determination of carbonation depth, a solution of $1 \%$ phenolphthalein was prepared by dissolving $1 \mathrm{gm}$ of phenolphthalein in $90 \mathrm{ml}$ of ethanol. A $100 \mathrm{ml}$ of distilled water was further added in the solution. All samples were split into two halves. The split up concrete specimens were then sprayed with phenolphthalein solution, the depth of the un-colored layer was measured at 4 positions and the average value was reported as carbonation depth as per BS EN 14630.

\section{RESULTS AND DISCUSSIONS \\ 3.1 Corrosion Potentials}

The corrosion potentials of all the mixes were determined at the age of 30 days and 180 days respectively, and are shown in Fig. 2. As reported by the standard ASTM C876-09 [10], if corrosion potential is less than a numerical value of $-200 \mathrm{mV}$, there is $90 \%$ likelihood that no corrosion is occurring in reinforcing steel. If the potential is in the range from -200 to $-350 \mathrm{mV}$, there is $50 \%$ likelihood that corrosion is occurring in reinforcing steel and if the potential is greater than a numerical value of $-350 \mathrm{mV}$, there is $90 \%$ likelihood that corrosion is occurring in reinforcing steel at the time of the measurement.

The results of corrosion potential at the 30 and 180 days for control concrete mix and modified mixes are shown in Fig. 2.

Fig. 2 shows $90 \%$ corrosion is active in the control mix at the age of 30 days and 180 days, it means $90 \%$ likelihood of corrosion. Such proportion of corrosion is because of enough calcium hydroxide in control mix that paves the way for carbonation. Fig. 2 also indicates that in rice husk ash modified concrete there is only $50 \%$ chance of corrosion at the age of 30 days. The effect of corrosion potential in rice husk ash modified concrete at the age of 30 days is reduced as compared to control mix. By the contrast, the risk of corrosion potential in rice husk ash modified concrete increases at the age of 180 days. The increased risk of corrosion potential is because of the reduced carbonation process that is lowering the $\mathrm{pH}$ value of concrete and causing the risk of corrosion potential.

As shown in Fig. 2, with the addition of RPP from 1 to $7.5 \%$ there is a $50 \%$ chance of corrosion at 30 days. Furthermore, in up to $5 \%$ dosages in the rice husk ashmodified mix a reduced chance of corrosion (from 90 to $50 \%$ ) has been observed at the age of 180 days. Such findings are supported by Brenna, A., et al. [11]. Furthermore, more inclusion of RPP dosages in the rice husk ash-modified mix causes an increased chance of corrosion from 50 to $90 \%$ at 180-days. An increased chance of corrosion with the further addition of RPP is due to the fact that polymer modified mortars and concrete entrap air from the atmosphere as reported by Ohama [12] and when oxygen from air and water accesses to the steel reinforcing bars embedded in concrete it results in the corrosion of the steel bars [13].

Table 1 Concrete mix proportions and sample marks

\begin{tabular}{|c|c|c|c|c|c|c|c|c|c|c|}
\hline S. No & Concrete Mix & $\begin{array}{c}\text { Cement } \\
\mathrm{kg} / \mathrm{m}^{3}\end{array}$ & $\begin{array}{l}\text { RHA } \\
\mathrm{kg} / \mathrm{m}^{3}\end{array}$ & $\begin{array}{c}\mathrm{RPP} \\
\mathrm{kg} / \mathrm{m}^{3} \\
\end{array}$ & $\begin{array}{c}\text { T. Binder } \\
\mathrm{kg} / \mathrm{m}^{3}\end{array}$ & $\begin{array}{c}\text { Plasticizer } \\
\mathrm{kg} / \mathrm{m}^{3}\end{array}$ & $\begin{array}{l}\text { Water } \\
\mathrm{kg} / \mathrm{m}^{3}\end{array}$ & $\begin{array}{c}\text { F. A } \\
\mathrm{kg} / \mathrm{m}^{3}\end{array}$ & $\begin{array}{c}\text { C. A } \\
\mathrm{kg} / \mathrm{m}^{3} \\
\end{array}$ & $\begin{array}{l}\text { Workability } \\
\text { range }(\mathrm{mm})\end{array}$ \\
\hline 1 & $\mathrm{CM}$ & 346 & 0 & 0.0 & 346.0 & 0.0 & 190.3 & 692 & 1038 & \multirow{6}{*}{$25-50$} \\
\hline 2 & RHAMM & 311.4 & 34.6 & 0.0 & 346.0 & 0.0 & 205.8 & 692 & 1038 & \\
\hline 3 & RHAPMM1 & 311.4 & 34.6 & 3.1 & 349.1 & 2.79 & 205.8 & 692 & 1038 & \\
\hline 4 & RHAPMM2.5 & 311.4 & 34.6 & 7.8 & 353.8 & 2.83 & 205.8 & 692 & 1038 & \\
\hline 5 & RHAPMM5 & 311.4 & 34.6 & 15.6 & 361.6 & 2.89 & 205.8 & 692 & 1038 & \\
\hline 6 & RHAPMM7.5 & 311.4 & 34.6 & 23.4 & 369.4 & 2.95 & 205.8 & 692 & 1038 & \\
\hline
\end{tabular}

CM (control mix), RHAMM (Rice Husk Ash Modified Mix), RHAPMM (Rice Husk Ash Polymer Modified Mix), the numbers 1, 2.5, 5 and 7.5 show percentage doses of Re-dispersible Polymer Powder (RPP). 


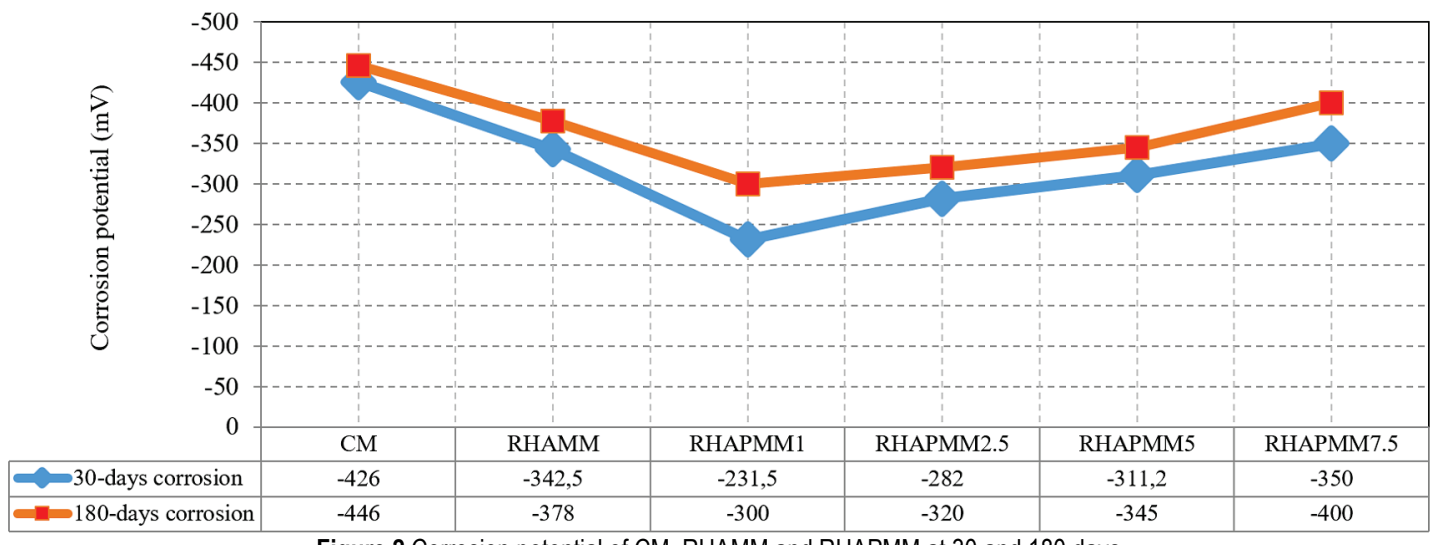

Figure 2 Corrosion potential of CM, RHAMM and RHAPMM at 30 and 180 days

\subsection{Carbonation Depth}

The carbonation effect on all the mixes exposed in lime-saturated solution was determined at the age of 30 days and 180 days (Fig. 3). It can be seen that not any effect of carbonation is noticed in all mixes up to the age of 30 days. The effect of carbonation at the age of 180 days is obvious in control mix and all modified mixes. The results show that the carbonation depth of control mix is $33 \mathrm{~mm}$ at the age of 180 days; this is due to the presence of enough calcium hydroxide. The carbonation depth in rice husk ash modified concrete is $23 \mathrm{~mm}$ at the age of 180 days. The reduction in carbonation effect in rice husk ash modified concrete as compared to control mix is mainly the consumption of calcium hydroxide by the supplementary cementing material.

However, the carbonation effect further kept on decreasing with the addition of a polymeric compound in rice husk ash modified concrete. The carbonation depth reduced from $23 \mathrm{~mm}$ to $8 \mathrm{~mm}$ due to the inclusion of redispersible polymer powder in rice husk ash modified concrete. The higher carbonation resistance in the Rice Husk Polymer-modified Concrete (RHAPMC) is due to the presence of impermeable films; such findings are supported by researcher Li, G., et al. [14] and by researcher Ohama $[12,15]$.

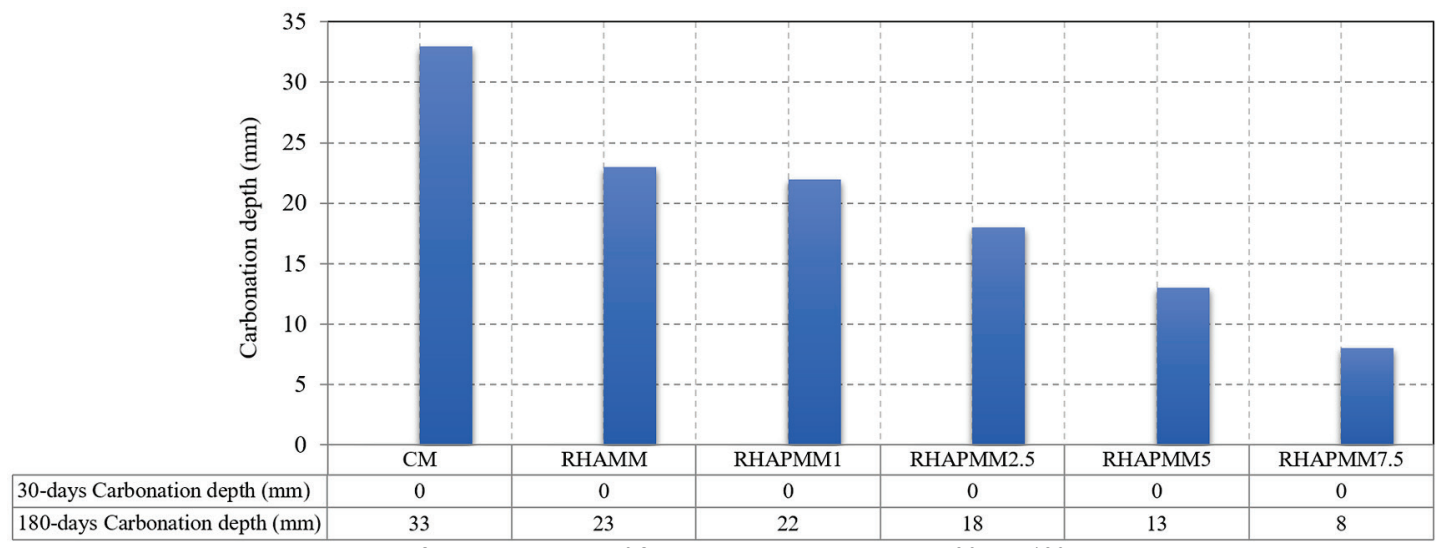

Figure 3 Carbonation depth of CM, RHAMM and RHAPMM at 30 and 180 days

\section{CONCLUSIONS}

In this paper, the effect of corrosion and carbonation on rice husk ash polymer modified concrete is investigated. The main conclusions drawn from this study are:

- The risk of corrosion at 180 days is $90 \%$ active in control and rice husk ash concrete, while with the addition of Re-dispersible Polymer Powder (RPP) from 1 to $5 \%$ dosage, the risk of corrosion is decreased to $50 \%$.

- Though there is not any effect of carbonation at the age of 30 days, yet there is a drastic effect of carbonation at the age of 180 days in control and rice husk ash modified concrete. However, with the addition of RPP from 1 to $7.5 \%$ dosages in the rice husk ash modified mix, the carbonation depth is reduced considerably.

\section{Acknowledgement}

The authors express their thanks to Civil Engineering Department QUEST Nawabshah for necessary support.

\section{REFERENCES}

[1] Alp, I., Deveci, H., Süngün, Y. H., Yilmaz, A. O., Kesimal, A., \& Yilmaz, E. (2009). Pozzolanic characteristics of a natural raw material for use in blended cements. Iranian Journal of Science and Technology, 33(B4), 291.

[2] Thomas, M. (2007). Optimizing the use offly ash in concrete, Portland Cement Association Skokie, IL, USA

[3] Mehta, P. K. (1992). Advances in Concrete Technology, $407-$ 431

[4] Saraswathy, V. \& Song, H. W. (2007). Corrosion performance of rice husk ash blended concrete. Construction and Building Materials, 21(8), 1779-1784. https://doi.org/10.1016/j.conbuildmat.2006.05.037 
[5] Ohama, Y. (1995). Handbook of polymer-modified concrete and mortars: properties and process technology, William Andrew. https://doi.org/10.1016/B978-081551373-5.50013-1

[6] Diamanti, M. V., Brenna, A., Bolzoni, F. A. B. I. O., Berra, M., Pastore, T., \& Ormellese, M. (2013). Effect of polymer modified cementitious coatings on water and chloride permeability in concrete. Construction and Building Materials, 49, 720-728. https://doi.org/10.1016/j.conbuildmat.2013.08.050

[7] Kumar Mehta, P. (2000). Durability-critical issues for the future.

[8] Neville, A. M. \& Brooks, J. J. (1987). Concrete technology, Longman Scientific \& Technical; J. Wiley, Harlow, Essex, UK; New York.

[9] Aggarwal, L. K., Thapliyal, P. C., \& Karade, S. R. (2007). Properties of polymer-modified mortars using epoxy and acrylic emulsions. Construction and Building Materials, 21(2), 379-383. https://doi.org/10.1016/j.conbuildmat.2005.08.007

[10] ASTM C876 - 09. Standard Test Method for Corrosion Potentials of Uncoated Reinforcing Steel in Concrete ASTM International, West Conshohocken (2009).

[11] Brenna, A., Bolzoni, F., Beretta, S., \& Ormellese, M. (2013). Long-term chloride-induced corrosion monitoring of reinforced concrete coated with commercial polymermodified mortar and polymeric coatings. Construction and Building Materials, 48, 734-744. https://doi.org/10.1016/j.conbuildmat.2013.07.099

[12] Ohama, Y. (1984). Concrete Admixtures Handbook: Properties, Science \& Technology. Park Ridge, New Jersey, USA: Noyes Publications, 337-429.

[13] Revie, R. W. (2011). Uhlig's Corrosion Handbook, Wiley. https://doi.org/10.1002/9780470872864

[14] Li, G., Guo, C., Gao, X., Ji, Y., \& Geng, O. (2016). Time dependence of carbonation resistance of concrete with organic film coatings. Construction and Building Materials, 114, 269-275. https://doi.org/10.1016/j.conbuildmat.2016.03.198

[15] Ohama, Y. (1987). Principle of latex modification and some typical properties of latex-modified mortars and concretes adhesion; binders (materials); bond (paste to aggregate); carbonation; chlorides; curing; diffusion. Materials Journal, 84(6), 511-518. https://doi.org/10.14359/2463

\section{Contact information:}

Daddan Khan BANGWAR, Dr, Assistant Professor

Department of Civil Engineering, Quaid-e-Awam University of Engineering,

Science \& Technology, Nawabshah, Sindh, Pakistan

E-mail: daddan@quest.edu.pk

Abdullah SAAND, Professor, Dr, Professor

Department of Civil Engineering, Quaid-e-Awam University of Engineering

Science \& Technology, Nawabshah, Sindh, Pakistan

E-mail: abdullah@quest.edu.pk

Muhammad Aslam BHUTTO, Dr, Assistant Professor

Department of Civil Engineering, NED University of Engineering \& Technology,

Karachi, Sindh, Pakistan

E-mail: mabhutto@neduet.edu.pk

Muhammad Auchar ZARDARI, Dr, Assistant Professor

Department of Civil Engineering, Quaid-e-Awam University of Engineering,

Science \& Technology, Nawabshah, Sindh, Pakistan

E-mail: muhammad.auchar@quest.edu.pk

Manthar Ali KEERIO, Dr, Assistant Professor

Department of Civil Engineering, Quaid-e-Awam University College of

Engineering, Science \& Technology, Larkano, Sindh, Pakistan

E-mail: mantharali99@quest.edu.pk 